Jurnal Indonesia Sosial Teknologi: p-ISSN: 2723 - 6609

e-ISSN : 2745-5254

Vol. 2, No. 7 Juli 2021

\title{
PERLINDUNGAN HUKUM BAGI KONSUMEN ATAS TRANSAKSI BARANG ELEKTRONIK MELALUI TRANSAKSI JUAL-BELI ONLINE SHOPEE
}

\section{Fially Claude Makasuci, Elisatris Gultom}

Faculty of Law, University Padjadjaran, Bandung, Indonesia

Email: fially20001@mail.unpad.ac.id

\begin{abstract}
Abstrak
Perkembangan teknologi informasi telah merubah kebiasaan masyarakat dalam melakukan transaksi jual beli. Kebiasaan masyarakat yang sebelumnya melakukan transaksi jual beli secara langsung atau dengan tatap muka, kini perlahan berubah menjadi sebuah gaya baru yaitu transaksi jual beli melalui internet atau transaksi online. Tujuan dari penelitian ini adalah membahas mengenai perlindungan hukum terhadap konsumen dalam melakukan transaksi online dalam perspektif UndangUndang Nomor 8 Tahun 1999 tentang Perlindungan Konsumen. Proses transaksi online mempunyai karakteristik yang khas dimana media yang digunakan adalah internet sehingga antara pelaku usaha dengan konsumen tidak bertemu secara langsung. Kondisi tersebut disatu sisi sangat menguntungkan konsumen, karena konsumen mempunyai banyak pilihan untuk mendapatkan barang yang dibeli tetapi di sisi lain pelanggaran terhadap hak-hak konsumen sangat riskan terjadi, maka dari itu diperlukan perlindungan hukum terhadap konsumen dalam transaksi online. Metode penelitian ini adalah deskriptif analitis, yang mengungkapkan peraturan perundang-undangan yang berkaitan dengan teori-teori hukum yang menjadi objek penelitian. Kesimpulan dari penelitian ini adalah konsumen yang dirugikan dapat mengajukan tuntutan yang kiranya sejalan dengan UUPK dan UU ITE sehingga memberikan kepastian hukum bagi konsumen. Pemerintah dan masyarakat juga memiliki peran yang penting dalam perlindungan konsumen melalui fungsi pengawasan.
\end{abstract}

Kata Kunci: perlindungan konsumen; sengketa konsumen; transaksi online.

\section{Abstract}

The development of information technology has changed people's habits in buying and selling transactions. The habit of people who previously carried out buying and selling transactions directly or face to face, is now slowly turning into a new style, namely buying and selling transactions via the internet or online transactions. The purpose of this study is to discuss the legal protection of consumers in conducting online transactions in the perspective of Law Number 8 of 1999 concerning Consumer Protection. The online transaction process has distinctive characteristics where the media used is the internet so that business actors and consumers do not meet directly. This condition on the one hand is very beneficial for consumers, because consumers have many choices to get the goods purchased but on the other hand violations of consumer rights are very risky, therefore legal protection is needed for consumers in online transactions. This research method is descriptive 
analytical, which reveals the laws and regulations relating to legal theories that are the object of research. The conclusion of this study is that consumers who are disadvantaged can file claims that are in line with the UUPK and UU ITE so as to provide legal certainty for consumers. The government and society also have an important role in consumer protection through a supervisory function.

Keyword: consumer protection; consumer disputes; online transactions

\section{Pendahuluan}

Perkembangan teknologi informasi telah merubah kebiasaan masyarakat dalam melakukan transaksi jual beli. Kebiasaan masyarakat yang sebelumnya melakukan transaksi jual beli secara langsung atau dengan tatap muka, kini perlahan berubah menjadi sebuah gaya baru yaitu transaksi jual beli melalui internet atau transaksi online (Zendrato, 2019). Transaksi online merupakan cara baru dalam melakukan kegiatan jual beli dengan memanfaatkan kemajuan teknologi informasi. Tansaksi online berkembang dimasyarakat sebagai dampak dari adanya perkembangan teknologi serta semakin meningkatnya jumlah pengguna internet di Indonesia. Dewasa ini banyak pelaku usaha dan konsumen melakukan transaksi jual-beli melalui online.

Sedangkan faktor yang mendorong konsumen melakukan transaksi online karena melalui transaksi online konsumen mendapatkan manfaat serta kemudahan antara lain dapat memilih beragam barang yang diinginkan selain itu konsumen tidak perlu pergi ke toko untuk sekedar membeli barang yang dibutuhkan, apalagi jika toko tersebut berada jauh dari konsumen, tentu hal ini sangat membantu konsumen karena dapat menghemat waktu sekaligus mempermudah konsumen (Hardika \& Ardianto, 2015). Melalui transaksi online cukup dengan mengakses situs-situs yang menawarkan barang kebutuhan, konsumen sudah dapat memilih dan membandingkan kualitas serta harga barang yang diinginkan, hal ini dirasa lebih praktis dan hemat dibandingkan dengan membeli secara langsung dengan pergi ketoko.

Meskipun demikian, pemanfaatan teknologi internet untuk melakukan transaksi online mempunyai dampak negatif pada konsumen (Aco \& Endang, 2017). Mengingat pembelian melalui transaksi online dilakukan oleh pelaku usaha dan konsumen yang tidak bertatap muka secara langsung serta tidak saling mengenal dengan kata lain transaksi online dilakukan atas rasa kepercayaan dari para pihak, permasalahan yang dapat terjadi pada transaksi online antara lain, yaitu bahwa kualitas barang yang dipesan tidak sesuai dengan apa yang dijanjikan oleh pelaku usaha, waktu pengiriman tidak sesuai dengan waktu yang telah disepakati, dalam proses pengiriman barang juga rawan terjadi kerusakan. Permasalahan lain yang dapat terjadi yaitu barang yang telah dipesan dan dibayar oleh konsumen tidak dikirim oleh pelaku usaha.

Seperti kasus yang dialami oleh Prajna Satria, peristiwa ini bermula saat Prajna browsing di internet dan melihat iklan penjualan laptop merk Vaio yang dipasang pelaku usaha di situs jual beli online (Hardika \& Ardianto, 2015). Saat dihubungi, pelaku usaha meminta Prajna untuk mentransfer uang sebesar Rp 2.850.000. Pelaku 
usaha tersebut menjanjikan akan mengirim laptop setelah uang ditransfer, setelah ditransfer sesuai dengan kesepakatan namun barang yang dijanjikan yaitu laptop tidak dikirim oleh pelaku usaha dan pelaku usaha tersebut tidak bisa dihubungi kembali.

Transaksi elektronik yang dipraktekkan dalam transaksi online melahirkan kekuatan daya tawar yang tidak sejajar antara pelaku usaha dan konsumen. Dapat dijelaskan dengan kenyataan bahwa pelaku usaha yang menjual barang dan/atau jasanya secara online kerap mencantumkan kontrak baku, sehingga memunculkan daya tawar yang asimetris (unequal bargaining power). Lemahnya kedudukan konsumen dengan pelaku usaha dalam melakukan transaksi online tentu sangat merugikan konsumen dan telah melanggar hak konsumen yang diatur dalam Pasal 4 Undang-Undang Nomor 8 Tahun 1999 tentang Perlindungan Konsumen (Susanto, 2008).

Berdasarkan uraian diatas maka kepastian hukum terhadap perlindungan konsumen dalam transaksi online sangat diperlukan. Selain dikarenakan konsumen memiliki hak-hak yang penting untuk ditegakkan, hal ini juga untuk menumbuhkan kesadaran pelaku usaha mengenai pentingnya perlindungan konsumen sehingga tumbuh sikap yang jujur dan bertanggung jawab dalam berusaha. Selanjutnya tujuan perlindungan konsumen, adalah untuk mengangkat harkat hidup dan martabat konsumen, yaitu dengan cara menghindarkan dari hal negatif pemakaian barang dan/

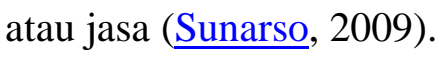

Pengaruh globalisasi dengan penggunaan sarana teknologi informasi dan komunikasi telah mengubah pola hidup masyarakat dan berkembang dalam tatanan kehidupan baru serta mendorong terjadinya perubahan sosial, budaya, pertahanan, keamanan, penegakan hukum dan tentunya dalam bidang ekonomi. Demikian pesatnya perkembangan dan kemajuan teknologi informasi, yang merupakan salah satu penyebab perubahan kegiatan kehidupan manusia dalam berbagai bidang yang secara langsung telah mempengaruhi lahirnya bentuk- bentuk perbuatan hukum baru (Halim, 2010).

Transaksi atau bisnis melalui virtual world (dunia maya) atau media internet yang disebut dengan istilah electronic commerce atau e-commerce, sudah cukup lama dikenal di Indonesia, terutama sejak dikenalnya credit cards, automated teller machines dan telephone banking. Istilah-istilah tersebut semakin banyak dikenal karena dipergunakan untuk keperluan yang luas, salah satunya dalam jual-beli (ㅆiru, 2012).

Sistem e-commerce juga memiliki kelemahan yaitu, ketidak sesuaian jenis dan kualitas barang yang dijanjikan, rentan aksi penipuan dimana banyak kasus ketika pembeli telah mengirim sejumlah uang yang disepakati tetapi barang yang di beli tidak di kirim, ketidaktepatan waktu pengiriman barang, ketidakamanan transaksi mulai dari, pembayaran menggunakan kartu kredit milik orang lain (pembajakan), akses ilegal ke sistem informasi (hacking), perusakan website sampai dengan pencurian data (BPKN, 2021a).

Salah satu e-commerce terbaik di Indonesia adalah Shopee. Shopee Indonesia adalah salah satu pusat perbelanjaan yang dikelola oleh Sea Group, dan di Indonesia dikelola oleh PT.Shopee Indonesia. Bisnis Customer to Costumer (C2C) mobile marketplace yang diusung Shopee memungkinkan kehadirannya dapat mudah diterima 
oleh berbagai lapisan masyarakat, termasuk di Indonesia. Sejak peluncurannya, Shopee Indonesia mengalami perkembangan yang sangat pesat, bahkan hingga Oktober 2017 aplikasinya sudah di download oleh lebih dari 80.000.000 (delapan puluh juta) pengguna. Menawarkan one stop mobile experience, Shopee menyediakan fitur live chat yang memudahkan para penjual dan pembeli untuk saling berinteraksi dengan mudah dan cepat (Wikipedia, 2021).

Akan tetapi pada kenyataannya, dalam transaksi jual beli online Shopee, terjadi pula praktik-praktik yang merugikan pembeli atau konsumen. Kasus pada Shopee yang di dapatkan melalui penelusuran adalah sebagai berikut:

1. Wanprestasi, terdapat ketidak sesuaian antara barang yang diterima dengan barang yang dipesan oleh konsumen (Qonsumen, 2021).

2. Pembatalan sepihak, pesanan dibatalkan sepihak oleh Shopee karena stok barang habis atau terjadi kesalahan program, padahal konsumen telah membayar lunas terlebih dahulu.

3. Pengaduan cukup sulit, konsumen yang memiliki masalah dengan pengiriman, pengembalian barang dan/atau dana, sering mendapat ketidak jelasan dari pihak Shopee jika melakukan komplain. Mulai dari proses yang lama, hingga komplain tidak diperhatikan (Konsumen Shopee, 2021) .

4. Pembobolan akun Shopee, akun konsumen dibobol kemudian pihak lain memanfaatkan data-data kartu kredit atau bank pemilik akun Shopee untuk disalahgunakan, seperti membeli barang dengan dana pemilik asli akun Shopee (Journal, 2021).

\section{Metode Penelitian}

Jenis penelitian yang digunakan dalam Penelitian ini adalah yuridis normatif. Jenis penelitian yuridis normatif mengacu kepada norma-norma hukum yang terdapat pada Peraturan Perundang-undangan, Kitab-Kitab Hukum, Putusan-putusan pengadilan, serta norma-norma hukum yang ada dalam masyarakat. Penelitian dengan yuridis normatif ditujukan kepada penelitian terhadap asas-asas hukum, sistematika hukum, dan taraf sinkronisasi hukum.Jenis penelitian yuridis normatif mengacu kepada normanorma hukum yang ada dalam masyarakat. Selain itu, juga melihat sinkronisasi suatu aturan dengan dengan aturan lainnya secara hierarki.

Penelitian ini bersifat deskriptif analitis, yang mengungkapkan peraturan perundang-undangan yang berkaitan dengan teori-teori hukum yang menjadi objek penelitian (Soendari, 2012). Penelitian deskriptif adalah "penelitian yang bertujuan untuk melukiskan tentang sesuatu hal di daerah tertentu dan pada saat tertentu". Sebelum penelitian ini dilaksanakan, harus terlebih dahulu mempunyai gambaran yang berupa data awal tentang permasalahan yang akan diteliti. Dalam penelitian ini, akan di gambarkan sejelas mungkin mengenai pelaksanaan perlindungan hukum yang diberikan terhadap konsumen yang dirugikan dalam transaksi jual beli pada situs belanja online Shopee. 
Sumber data yang digunakan dalam penelitian ini adalah data primer dan data sekunder. Data primer merupakan data yang didapat langsung dari masyarakat sebagai sumber pertama dengan melalui penelitian lapangan seperti melalui wawancara dan observasi. Sedangkan data sekunder merupakan data yang diperoleh dari dokumendokumen resmi, buku-buku yang berhubungan dengan objek penelitian, hasil penelitian dalam bentuk laporan, Penelitian, tesis, disertasi, dan peraturan perundang-undangan.

\section{Hasil dan Pembahasan}

Menurut Undang-Undang No. 8 Tahun 1999 tentang Perlindungan Konsumen, salah satu hak dasar konsumen yang harus dilindungi adalah kepastian hukum. Permasalahan dalam kepastian hukum e-commerce, misalnya mengenai keabsahan transasksi bisnis dari aspek hukum perdata. Permasalahan lain yang timbul misalnya berkenaan dengan jaminan keaslian data, kerahasiaan dokumen, kewajiban sehubungan dengan pajak, hukum yang ditunjuk jika terjadi pelanggaran perjanjian atau kontrak, masalah yurisdiksi hukum dan juga masalah hukum mana yang harus diterapkan bila terjadi sengketa. Jaminan keamanan transaksi e-commerce sangat diperlukan untuk melindungi konsumen agar semakin menumbuhkan kepercayaan konsumen, dan pada akhirnya diharapkan terjadi peningkatan volume transaksi melalui e-commerce (BPKN, 2021).

Peraturan mengenai E-commerce selanjutnya diatur dalam Undang- Undang No. 11 Tahun 2008 Undang-Undang Informasi dan Transaksi Elektronik (Selanjutnya disingkat UUITE). Perdagangan melalui sistem elektronik kemudian diatur pada Pasal 65 dan Pasal 66 Undang-Undang No. 7 Tahun 2014 tentang Perdagangan.

Ditetapkannya Undang-Undang yang berkaitan dengan E-Commerce, menandakan perhatian dan keseriusan pemerintah dalam mengatur regulasi perlindungan konsumen di Indonesia. Akan tetapi, pelaksanaan penegakannya dalam dunia transaksi elektronik juga masih jauh dari harapan. Masih banyak kasus-kasus yang penyelesaiannya tidak maksimal dan cenderung mengabaikan hak-hak konsumen. Banyak sekali pula kasus-kasus yang sama sekali tidak ada penyelesaian nya, karena konsumen cenderung lebih memilih untuk tidak mempermasalahkannya.

\section{Posisi Konsumen dalam Transaksi Online}

Menurut Pasal 1 ayat 2 Undang-Undang Nomor 8 Tahun 1999 tentang Perlindungan Konsumen, konsumen adalah "setiap orang pemakai barang dan/atau jasa yang tersedia dalam masyarakat, baik bagi kepentingan diri sendiri, keluarga, orang lain maupun makhluk hidup lain dan dan tidak untuk diperdagangkan" Konsumen dalam pembahasan ini yaitu konsumen yang membeli suatu produk melalui online dimana produk tersebut dimanfaatkan secara langsung dan tidak untuk dijual kembali atau konsumen akhir. Secara garis besar terdapat beberapa permasalahan yang terjadi pada proses transaksi online, yaitu :

1) Konsumen tidak dapat langsung mengidentifikasi, melihat, atau menyentuh barang yang akan dipesan; 
2) Ketidak jelasan informasi tentang produk yang ditawarkan dan/atau tidak ada kepastian apakah konsumen telah memperoleh berbagai informasi yang layak diketahui, atau yang sepatutnya dibutuhkan untuk mengambil suatu keputusan dalam bertransaksi;

3) Tidak jelasnya status subjek hukum, dari pelaku usaha;

4) Tidak ada jaminan keamanan bertransaksi dan privasi serta penjelasan terhadap risiko- risiko yang berkenaan dengan sistem yang digunakan, khususnya dalam hal pembayaran secara elektronik baik dengan credit card maupun electronic cash;

5) Pembebanan risiko yang tidak berimbang, karena umumnya terhadap jual beli di internet, pembayaran telah lunas dilakukan di muka oleh konsumen, sedangkan barang belum tentu diterima atau akan menyusul kemudian, karena jaminan yang ada adalah jaminan pengiriman barang bukan penerimaan barang;

6) Transaksi yang bersifat lintas batas negara borderless, menimbulkan pertanyaan mengenai yurisdiksi hukum negara mana yang sepatutnya diberlakukan. Mengingat transaksi online dilakukan dengan tanpa tatap muka secara langsung dan antara konsumen dan pelaku usaha tidak saling mengenal, maka hak-hak konsumen pada transaksi online sangat rawan terlanggar sehingga menempatkan konsumen pada posisi tawar (bargaining position) yang lemah. Maka dari itu diperlukan adanya perlindungan hukum terhadap hak-hak konsumen dalam transaksi online.

\section{Perlindungan Hukum Terhadap Konsumen yang dirugikan Dalam Tansaksi} Jual Beli Barang Elektronik Pada Situs Belanja Online SHOPEE

\section{A. Transaksi E-Commerce}

\section{Pengertian E-Commerce}

Menurut Julian Ding sebagaimana dikutip oleh Mariam Darus Badrulzaman, definisi e-commerce adalah sebagai berikut: "E-commerce is a dynamic sets of technologies, application, and business process that link enterprises, consumers and communities through electronic transaction and the electronic exchange of goods, services, and information". Artinya, ECommerce adalah satu set dinamis teknologi, aplikasi dan proses bisnis yang menghubungkan perusahaan, konsumen, dan komunitas tertentu melalui transaksi elektronik dan perdagangan barang, jasa, dan informasi yang dilakukan secara elektronik.

Electronic Commerce yaitu transaksi dagang antara penjual dan pembeli untuk menyediakan barang, jasa, atau mengambil alih hak. Kontrak ini dilakukan dengan media elektronik (digital medium) tanpa dihadiri para pihak yang melakukan transaksi. Media ini terdapat di dalam jaringan umum dengan sistem terbuka, yaitu internet atau world wide web, transaksi ini terjadi terlepas dari batas wilayah dan syarat nasional. 


\section{B. Hubungan Hukum antara Konsumen Shopee dan PT Shopee Indonesia}

\section{Pengaturan Hubungan Hukum antara Para Pihak}

Hubungan hukum (rechtbetrekkingen) adalah "hubungan antara dua subyek hukum atau lebih mengenai hak dan kewajiban di satu pihak berhadapan dengan hak dan kewajiban pihak yang lain". Hubungan hukum dapat terjadi antara sesama subyek hukum dan antara subyek hukum dengan benda. Hubungan antara sesama subyek hukum dapat terjadi antara orang, orang dengan badan hukum, dan antara sesama badan hukum. Hubungan hukum antara subyek hukum dengan benda berupa hak apa yang dikuasai oleh subyek hukum itu atas benda tersebut, baik benda berwujud, benda bergerak, atau benda tidak bergerak. Hubungan hukum memiliki syarat-syarat yaitu adanya dasar hukum dan adanya peristiwa hokum (Nugraha, 2017). Hubungan hukum memiliki syarat-syarat yaitu adanya dasar hukum dan adanya peristiwa hokum.

Hubungan hukum adalah hubungan yang terhadapnya hukum meletakkan hak pada satu pihak dan meletakkan kewajiban pada pihak lainnya. Apabila satu pihak tidak mengindahkan ataupun melanggar hubungan tadi, lalu hukum memaksakan supaya hubungan tersebut dipenuhi ataupun dipulihkan kembali. Selanjutnya, apabila satu pihak memenuhi kewajibannya, maka hukum memaksakan agar kewajiban tadi dipenuhi (Tutik \& SH, 2015).

Dalam pelaksanaan transaksi elektronik melalui situs belanja online shopee, maka akan terjadi suatu hubungan antara konsumen dengan PT. Shopee Indonesia. Oleh karena itu, dibuat suatu perjanjian yang disebut dengan kontrak elektronik yang memuat syarat dan ketentuan penggunaan situs belanja online shopee. Jika konsumen shopee menyatakan setuju dengan isi dari kontrak tersebut, maka konsumen tersebut harus membubuhkan tanda ceklis pada halaman yang telah disediakan. Perjanjian dalam kontrak tersebut termasuk dalam suatu kontrak perjanjian yang bentuk dan isinya ditentukan oleh salah satu pihak, dan pihak yang membuat adalah PT. Shopee Indonesia. Konsumen adalah para pengguna situs belanja shopee yang telah menyetujui kontrak elektronik yang telah dibuat oleh PT.Shopee Indonesia.

Hubungan hukum yang terjalin antara konsumen shopee dan PT.Shopee Indonesia dalam berkontrak pada umumnya untuk saling bertukar kepentingan. Membiarkan hubungan kontraktual para pihak semata-mata pada mekanisme kebebasan berkontrak sering kali menghasilkan ketidakadilan apabila salah satu pihak berada dalam posisi yang lemah. Hubungan hukum antara konsumen dan pelaku usaha dalam kebebasan berkontrak dapat digolongkan dalam tiga kategori, yaitu:

a. Hubungan hukum yang terjadi dengan menggunakan syarat-syarat baku, yaitu suatu klausula yang telah disediakan pengusaha dalam suatu konsep surat perjanjian tidak pernah dapat ditinjau kembali. Konsumen hanya dapat menerima syarat-syarat perjanjian itu atau tidak mengadakan perjanjian sama sekali. Kelebihan kemampuan pengusaha tertentu untuk menentukan sendiri syarat-syarat suatu perjanjian, tanpa dikoreksi kecuali konsumen bersedia untuk tidak mendapatkan barang dan/atau jasa yang dibutuhkannya, menyebabkan konsumen pada dasarnya kehilangan kebebasannya. Dalam kondisi demikian, 
bagi konsumen asas kebebasan dalam hukum perjanjian berarti tidak adanya kebebasan berkehendak;

b. Hubungan hukum secara sukarela, yaitu dapat terjadi antara konsumen dan produsen dengan mengadakan perjanjian tertentu. Dengan perjanjian atau persetujuan tersebut, seperti yang disebutkan dalam Pasal 1313 KUHPerdata, yaitu setiap perbuatan seseorang atau lebih yang mengikatkan diri dengan seorang atau lebih. Hubungan hukum itu menimbulkan hak dan kewajiban yang sama pada masing-masing pihak. Apabila salah satu pihak lalai dalam melaksanakan kewajibannya untuk memberikan sesuatu, berbuat atau tidak berbuat sesuatu sesuai perjanjian tersebut maka dapat terjadi perbuatan ingkar janji, cedera janji (wanprestasi);

c. Hubungan hukum tidak secara sukarela, yaitu terjadi tanpa adanya suatu persetujuan atau perjanjian yang disebabkan oleh suatu perbuatan atau kelalaian atau kurang hati-hati satu pihak yang menimbulkan kerugian. Pasal 1354 KUHPerdata diatur perbuatan melawan hukum yang menimbulkan kerugian pada pihak lain. Dalam hubungan hukum konsumen kaedah ini sangat penting oleh karena konsumen tidak pernah berhadapan atau mengadakan hubungan hukum secara langsung dengan pemilik atau penanggung jawab usaha.

\section{Hak dan Kewajiban Para Pihak}

Melalui hubungan hukum yang dilakukan antara PT.Shopee Indonesia dan konsumen shopee, maka sudah tentu akan menimbulkan hak dan kewajiban bagi para pihak, dimana kewajiban PT.Shopee Indonesia merupakan hak dari konsumen dan demikian pula sebaliknya kewajiban konsumen merupakan hak dari PT. Shopee Indonesia. Hak Shopee selaku media/sarana penunjang bisnis penyedia fitur dan layanan untuk menjamin keamanan dan kenyamanan para pengguna adalah sebagai berikut:

1. Shopee memiliki kewenangan untuk mengambil tindakan yang dianggap perlu terhadap akun yang diduga dan/atau terindikasi melakukan penyalahgunaan, memanipulasi, dan/atau melanggar aturan penggunaan di situs shopee, mulai dari melakukan moderasi, menghentikan layanan "Jual Barang", membatasi jumlah pembuatan akun, membatasi atau mengakhiri hak setiap pengguna untuk menggunakan layanan, maupun menutup akun tersebut tanpa memberikan pemberitahuan atau informasi terlebih dahulu kepada pemilik akun yang bersangkutan.

2. Shopee memiliki kewenangan untuk mengambil keputusan atas permasalahan yang terjadi pada setiap transaksi.

3. Jika pengguna gagal untuk mematuhi setiap ketentuan dalam aturan penggunaan di situs shopee, maka pihak shopee berhak untuk mengambil tindakan yang dianggap perlu termasuk namun tidak terbatas pada melakukan moderasi, mengehentikan layanan "Jual Barang", menutup akun dan/atau mengambil langkah hukum selanjutnya.

4. Shopee berhak untuk meminta data-data pribadi pengguna jika diperlukan. 
5. Aturan penggunaan situs shopee dapat berubah sewaktu-waktu dan/atau diperbaharui dari waktu ke waktu tanpa pemberitahuan terlebih dahulu. Dengan mengakses situs shopee, pengguna dianggap menyetujui perubahan-perubahan dalam aturan penggunaan Situs Shopee.

6. Shopee berhak menggunakan data dan informasi para pengguna situs demi meningkatkan mutu dan pelayanan di situs shopee.

Kewajiban Shopee selaku media/sarana penunjang bisnis penyedia fitur dan layanan untuk menjamin keamanan dan kenyamanan para pengguna adalah sebagai berikut:

1. Melindungi segala informasi yang diberikan pengguna pada saat pendaftaran, mengakses, dan menggunakan seluruh layanan dalam situsshopee.

2. Melindungi segala hak pribadi yang muncul atas informasi mengenai suatu produk yang ditampilkan oleh pengguna layanan situs shopee, baik berupa foto, username, logo, dan lain lain.

3. Memberitahukan data dan informasi yang dimiliki oleh para pengguna situs bila diwajibkan dan/atau diminta oleh institusi yang berwenang berdasarkan ketentuan hukum yang berlaku, perintah resmi dari pengadilan, dan/atau perintah resmi dari instansi/aparat yang bersangkutan.

4. Memberi kompensasi, ganti rugi dan/atau penggantian atas kerugian akibat kekeliruan sistem pada situs shopeeyang menyebabkan kerugian terhadap pihak pembeli maupun penjual.

5. Tunduk pada peraturan perundang-undangan Republik Indonesia pada setiap sistem yang dijalankan pada platformShopee.

Hak Konsumen Shopee yang diatur di dalam syarat dan ketentuan penggunaan dalam situs belanja online shopee adalah:

1. Berhak mendapatkan penjelasan secara rinci dan jelas mengenai penggunaan situs belanja online shopee.

2. Berhak mengajukan pertanyaan mengenai produk maupun layanan kepada customer care shopee melalui email ke support@shopee.co.id atau dengan formulir umpan balik yang dapat ditemukan pada aplikasi.

3. Berhak memberikan pemberitahuan terkait dengan hukum melalui email ke legal@ shopee.com

4. Berhak untuk memberikan penilaian atas pelayanan yang diberikan shopee melalui pemberian rating.

5. Berhak menerima ganti kerugian atas ketidaksesuaian produk yang diterima konsumen berupa pengembalian barang atau dana. Pembeli hanya boleh mengajukan permohonan pengembalian barang dalam situasi berikut:

a. Barang tersebut cacat dan/atau rusak saat diterima;

b. Penjual telah mengirimkan barang yang tidak sesuai dengan spesifikasi yang disepakati kepada pembeli;

c. Barang yang dikirimkan kepada pembeli secara material berbeda dengan daftar barang yang ada; 
6. Berhak untuk menerima pengakhiran akun dan/atau berhenti menggunakan layanan.

Kewajiban konsumen shopee yang diatur dalam syarat dan ketentuan penggunaan dalam situs belanja online shopee adalah:

1. Pembeli wajib mematuhi segala ketentuan penggunaan layanan yang telah ditetapkan oleh pihak shopee.

2. Pembeli wajib untuk menyetujui tindakan shopee untuk menggunakan,mengumpulkan, dan/atau mengolah konten, data pribadi, dan informasi pengguna.

3. Pembeli wajib untuk menyetujui dan mengakui bahwa hak kepemilikan atas informasi pengguna dimiliki secara bersama oleh pengguna layanan dan pihak shopee.

4. Pembeli wajib untuk membayar produk sesuai dengan kesepakatan dengan penjual

5. Pembeli wajib untuk memberikan data dan identitas yang akurat kepada pihak shopee.

\section{Perlindungan Hukum Terhadap Konsumen yang Dirugikan dalam Transaksi Jual Beli pada Situs Belanja Online Shopee}

Perlindungan hukum yang diberikan kepada konsumen Shopee ini, didasari oleh kerugian-kerugian yang seringkali dialami oleh konsumen shopee dalam kegiatan transaksi jual-beli nya melalui situs belanja online shopee. Melalui penelusuran yang telah dilakukan, bentuk-bentuk kerugian tersebut berupa:

1. Wanprestasi, terdapat ketidaksesuaian antara barang yang diterima dengan barang yang dipesan oleh konsumen.

2. Pembatalan sepihak, pesanan dibatalkan sepihak oleh Shopee karena stok barang habis atau terjadi kesalahan program, padahal konsumen telah membayar lunas terlebih dahulu

3. Pengaduan cukup sulit, konsumen yang memiliki masalah dengan pengiriman, pengembalian barang dan/atau dana, sering mendapat ketidakjelasan dari pihak Shopee jika melakukan komplain. Mulai dari proses yang lama, hingga komplain tidak diperhatikan

4. Pembobolan akun Shopee, akun konsumen dibobol kemudian pihak lain memanfaatkan data-data kartu kredit atau bank pemilik akun Shopee untuk disalahgunakan, seperti membeli barang dengan dana pemilik asli akun Shopee

Berdasarkan kerugian-kerugian yang dialami konsumen shopee seperti dikemukakan diatas, maka perlindungan hukum terhadap konsumen yang dapat diberikan adalah:

\section{Perlindungan Hukum Terhadap Konsumen Shopee berdasarkan Undang- Undang-Undang Nomor 8 Tahun 1999 tentang Perlindungan Konsumen.}

a. Hak Konsumen untuk Mengoptimalkan Pelayanan. 
Berdasarkan Undang-Undang Perlindungan Konsumen Pasal 4 mengenai hakhak konsumen, yaitu:

1) Hak atas informasi yang benar, jelas, dan jujur mengenai kondisi dan jaminan barang dan/ atau jasa;

2) Hak untuk didengar pendapat dan keluhannya atas barang dan/ atau jasa yang digunakan;

3) Hak untuk mendapatkan advokasi, perlindungan, dan upaya penyelesaian sengketa perlindungan konsumen secara patut;

4) Hak untuk mendapat pembinaan dan pendidikan konsumen;

5) Hak untuk diperlakukan atau dilayani secara benar, jujur, serta tidak diskriminatif;

b. Hak Konsumen untuk Menuntut Penggantian Kerugian

Hukum memberi perlindungan kepada konsumen yang diatur dalam UUPK Pasal 19 mengenai Tanggung Jawab Pelaku Usaha, menyebutkan bahwa:

1. Pelaku usaha bertanggung jawab memberikan ganti rugi atas kerusakan pencemaran, dan/atau kerugian konsumen akibat mengkonsumsi barang dan/atau jasa yang dihasilkan atau diperdagangkan.

2. Ganti rugi sebagaimana dimaksud pada angka (1) dapat berupa pengembalian uang atau penggantian barang dan/atau jasa yang sejenis atau setara nilainya, atau perawatan kesehatan dan/atau pemberian santunan yang sesuai dengan ketentuan peraturan perundang-undangan yang berlaku.

3. Pemberian ganti rugi dilaksanakan dalam tenggang waktu 7(tujuh) hari setelah tanggal transaksi.

4. Pemberian ganti rugi sebagaimana dimaksud pada angka (1) dan angka (2) tidak menghapuskan kemungkinan adanya tuntutan pidana berdasarkan pembuktian lebih lanjut mengenai adanya unsur kesalahan.

5. Ketentuan sebagaimana dimaksud pada angka (1) dan angka (2) tidak berlaku apabila pelaku usaha dapat membuktikan bahwa kesalahan tersebut merupakan kesalahan konsumen.

Mengenai masalah ganti rugi ini sebenarnya sangat terkait dengan tanggung jawab pelaku usaha. Dalam Pasal 19 UUPK, dinyatakan bahwa "pelaku usaha memiliki tanggung jawab untuk memberikan ganti rugi atas kerugian konsumen akibat mengkonsumsi barang dan/atau jasa yang dihasilkan atau diperdagangkan”. Ganti rugi tersebut dapat berupa:

1) Pengembalian uang atau penggantian barang dan/atau jasa yang sejenis atau setara;atau

2) Perawatan kesehatan dan/atau pemberian santunan yang sesuai dengan ketentuan peraturan perundang-undangan yang berlaku.

c. Hak Konsumen untuk Mengadukan Permasalahan

Dalam Pasal 4 UUPK diatur mengenai hak-hak dari konsumen diantaranya disebutkan mengenai hak untuk mendapatkan advokasi, perlindungan, dan upaya penyelesaian sengketa secara patut. 
d. Menyelesaikan Sengketa Konsumen

Setiap sengketa yang terjadi antar konsumen dan pelaku usaha setidaknya dapat dilakukan dengan 2 cara penyelesaian, yaitu:

1) Penyelesaian sengketa secara damai.

2) Penyelesaian melalui lembaga atau instansi yang berwenang.

2. Perlindungan Hukum Kepada Konsumen Shopee berdasarkan UndangUndang Nomor 11 Tahun 2008 tentang Informasi dan Transaksi Elektronik Menyadari adanya beberapa kelemahan dalam Undang-Undang Perlindungan Konsumen (UUPK), Pemerintah bersama DPR mengundangkan UndangUndang Nomor 11 tahun 2008 tentang Informasi dan Transaksi Elektronik (UU ITE). Beberapa pasal dalam UU ITE ini berusaha menutup kelemahan UUPK dalam hal perlindungan terhadap hak-hak konsumen. Dapat dilihat dari Pasal 9 UU ITE: "Pelaku usaha yang menawarkan produk melalui sistem elektronik harus menyediakan informasi yang lengkap dan benar berkaitan dengan syarat kontrak, produsen, dan produk yang ditawarkan". Kemudian Pasal 10 menyatakan mengenai syarat sertifikasi keandalan bagi pelaku usaha serta Pasal 2 dan Pasal 18 yang memberikan solusi bagi permasalahan pilihan hukum dan pilihan forum mengadili apabila transaksi elektronik melibatkan pihak yang berkedudukan hukum di negara lain.

Sebagai pelaku transaksi elektronik, shopee tunduk kepada tata aturan hukum yang berlaku di dalam Undang-Undang Nomor 11 tahun 2008 tentang Informasi dan Transaksi Elektronik. Terdapat aturan dalam pasal 17 UU ITE yang menyebutkan bahwa: "Para pihak yang melakukan transaksi elektronik wajib beritikad baik dalam melakukan interaksi dan/atau pertukaran informasi elektronik dan/atau dokumen elektronik selama transaksi berlangsung”.

Selanjutnya, ketentuan transaksi elektronik diatur dalam Pasal 18 UU ITE, yaitu: "Transaksi elektronik yang dituangkan ke dalam kontrak elektronik mengikat para pihak". Bentuk perlindungan hukum terhadap konsumen dalam transaksi jual beli pada situs belanja shopee, yang diatur dalam Undang-Undang nomor 11 tahun 2008 tentang Informasi dan Transaksi Elektronik adalah:

a. Perlindungan Terhadap Data Pribadi

Undang-Undang Informasi dan Transaksi Elektronik sudah cukup memadai dalam mengakomodasi perlindungan terhadap data pribadi konsumen.

\section{b. Otensitas Subjek Hukum}

Yang menyangkut otensitas adalah kecakapan para pihak sebagaimana tertuang dalam Pasal 1320 Kitab Undang-Undang Hukum Perdata dan validitas subjek hukum.

c. Objek Transaksi E-commerce

Undang-Undang nomor 11 tahun 2008 tentang Informasi dan Transaksi Elektronik mewajibkan pelaku usaha untuk menyediakan informasi yang 
lengkap dan benar berkaitan dengan produk yang ditawarkan, sebagaimana disebutkan dalam Pasal 9.

Undang-Undang nomor 11 tahun 2008 tentang Informasi dan Transaksi Elektronik juga melarang penyebaran berita bohong dan menyesatkan yang mengakibatkan kerugian konsumen dalam transaksi elektronik, sebagaimana diatur dalam Pasal 28 ayat (1).

\section{Tanggung Jawab Shopee dalam Transaksi Jual-Beli Barang Elektronik.}

Shopee merupakan e-commerce yang menjembatani penjual dan pembeli utuk mempermudah transaksi jual beli online melalui perangkat elektronik. Shopee dalam hal ini bertindak sebagai penyedia tempat, yakni berupa website untuk para Penjual membuka usahanya yang berupa toko dan bertindak sebagai pihak ketiga/perantara antara Penjual dan Pembeli.Shopee dalam hal ini dapat juga disebut sebagai marketplace, yaitu tempat antara konsumen dan penjual melakukan transaksinya

Setiap transaksi yang dilakukan oleh Penjual dan Pembeli akan diawasi oleh pihak Shopee, dan menjadi tanggung jawab Shopee. Shopee yang bertindak sebagai pengelola website dan sebagai pihak ketiga juga memiliki tanggung jawab kepada setiap konsumen. Tanggung jawab Shopee bukan berbentuk penggantian barang dalam bentuk fisik, melainkan tangung jawab Shopee tercermin dalam hal-hal sebagai berikut, yaitu:

1. Menyediakan sarana pelaporan. Dalam hal ini, Shopee memiliki tanggung jawab untuk menyediakan sarana pelaporan yang memadai terhadap setiap keluhan konsumen. Hal tersebut telah tercermin dari pemberian fasilitas aduan 24 (duapuluh empat) jam melalui customer care shopee di nomor 150072 atau melalui email ke cs@shopee.co.id. Pembeli dapat menyampaikan segala bentuk keluhannya melalui contact yang tersedia dan dengan menunjukkan bukti-bukti yang valid, kemudian pihak Shopee akan menulusuri keluhan tersebut.

2. Melakukan penghapusan dan pemblokiran terhadap konten terlarang. Dalam hal transaksi melalui website e-commerce, kerap kali muncul sebuah iklan (ads) yang menampilkan konten-konten negatif yang berbau pornografi, yang sangat mengganggu konsumen dalam melakukan transaksi jual beli di Shopee. Shopee memiliki tanggung jawab untuk menyaring segala jenis konten yang masuk dan melakukan pemblokiran terhadap konten-konten negatif tersebut. Konsumen Shopee juga memiliki hak untuk melakukan pelaporan kepada Pihak Shopee terkait dengan konten yang menganggu tersebut.

3. Perlindungan terhadap data-data pribadi konsumen. Pada saat konsumen melakukan transaksi jual beli di Shopee, Shopee menghendaki setiap konsumennya untuk mengisi data-data diri yang selengkap-lengkap nya dan valid. Begitu juga halnya, ketika konsumen melakukan transaksi pembayaran 
melalui kartu kredit, maka Shopee akan meminta konsumen tersebut untuk memasukkan data kartu kredit tersebut dengan selengkap- lengkapnya. Atas dasar hal tersebut, maka Pihak Shopee memiliki tanggung jawab untuk melindungi data-data konsumen dari pihak-pihak yang tidak bertanggung jawab yang ingin melakukan pencurian akan data- data tersebut melalui peretasan akun.Shopee menyediakan fitur "3D Secure" untuk melindungi konsumen yang melakukan pembayaran dengan kartu kredit. Fitur $3 D$ Secure ini merupakan bentuk kerjasama antara Shopee dengan pihak penyedia kartu kredit (seperti visa, mastercard, dan paypal) untuk melindungi data-data kartu kredit konsumen.

4. Shopee memiliki tanggung jawab untuk menyeleksi Penjual-Penjual yang hendak membuka tokonya di website Shopee. Dalam hal ini Shopee menghendaki setiap calon Penjual untuk melakukan pengisian form pendaftaran dengan sebenar-benarnya, dan didukung dengan menguploadfoto KTP sebagai bukti bahwa calon Penjual tersebut merupakan individu sungguhan dan bukan Penjual "fiktif".

5. Dalam hal Penjual yang tidak mengirimkan barangnya dalam jangka waktu yang ditentukan. Sesuai ketentuan prosedural transaksi melalui Shopee, sistem dalam Shopee akan secara otomatis menahan pembayaran yang telah dilakukan pembeli ke dalam rekening resmi Shopee (rekening ketiga) dan akan mengembalikan dana tersebut ke dalam ShopeePay milik Pembeli, atau dapat langsung dikembalikan ke rekening bank milik Pembeli yang akan diproses secara langsung dalam jangka waktu 24 jam. Apabila dalam hal ini Pembeli melakukan pembayaran dengan menggunakan kartu kredit, maka Pihak Shopee akan mengembalikan dana transaksi ke limit kartu kredit di tagihan berikutnya.Shopee juga akan melakukan tindakan terhadap penjual yang memiliki reputasi tidak baik, dan akan melakukan pemblokiran akun Penjual apabila secara berkali-kali terbukti melakukan tindakan yang hendak merugikan konsumen.

6. Tanggung jawab Shopee apabila terdapat barang yang cacat atau tidak sesuai dengan spesifikasi. Dalam hal ini, tanggung jawab Shopee tidak berupa pengantian fisik barang secara langsung, melainkan Shopee meyediakan fitur "pusat resolusi" yang berguna menjadi sarana konsumen untuk melakukan tuntutan kepada Penjual akan barang yang tidak sesuai dengan perjanjian. Shopee akan bertindak sebagai fasilitator melalui pencarian solusi, dan pengambilan keputusan akan wanprestasi yang terjadi tersebut. Pihak Penjual dan Pembeli diharapkan untuk mengirimkan bukti-bukti transaksi berupa foto barang, nota pembelian, slip resi pengiriman, dan bukti bukti penunjang lainnya yang dikeluarkan oleh masing-masing pihak. Shopee kemudian memiliki tanggung jawab untuk menjadi penengah akan permasalahan tersebut. 
7. Penyediaan garansi Shopee. Setiap pembelian yang dilakukan oleh Pembeli akan dilindungi oleh garansi Shopee. Garansi Shopee ini berlaku selama 7 hari. Apabila Pembeli hendak melakukan keluhan akan barang yang tidak sesuai spesifikasi, dan hendak melakukan tuntutan ganti rugi kepada Penjual, tuntutan tersebut harus dilakukan dalam jangka waktu sebelum 7 hari, karena setiap barang yang diperjual belikan dilindungi oleh garansi Shopee selama 7 hari. Apabila dalam jangka waktu lewat dari 7 hari Pembeli baru menyampaikan keluhannya, maka keluhan tersebut tidak dapat diproses, oleh karena itu Pembeli Shopee diharapkan untuk selalu menyimpan bukti invoice/nota pembelian elektronik dalam kegiatan transaksi di Shopee.

Tanggung jawab pelaku usaha diatur dalam Bab VI Undang-Undang Perlindungan Konsumen Pasal 19 sampai dengan Pasal 28. Dalam kaitannya dengan Shopee sebagai penyedia layanan jasa, Pasal 26 UUPK menyatakan: "Pelaku usaha yang memperdagangkan jasa wajib memenuhi jaminan dan/atau garansi yang disepakati dan/atau yang diperjanjikan".

Transaksi yang dilakukan dalam forum jual beli online akan menimbulkan hubungan hukum yang melibatkan setidaknya tiga pihak, yaitu pembeli (buyer), penjual (seller), dan website online (yang dalam hal ini adalah Shopee).Situs belanja Online Shopee dalam hal ini tidak terlibat secara langsung dalam pemenuhan tanggung jawab akan kerugian yang dialami konsumen, tetapi jika ada suatu permasalahan terhadap barang, maka Shopee akan meneruskannya kepada pihak penjual, dan Shopee akan memfasilitasi penggantian kerugian tersebut.

Shopee selalu berupaya untuk menjaga layanan agar tetap nyaman, aman, dan berfungsi dengan baik, tapi Shopee tidak dapat menjamin operasi terus menerus atau akses ke layanan Shopee dapat selalu sempurna. Informasi dan data dalam situs Shopee memiliki kemungkinan tidak terjadi secara real time. Untuk itu, Shopee juga memiliki batasan-batasan tanggung jawab, yaitu:

1. Penggunaan atau ketidakmampuan pengguna dalam menggunakan layanan Shopee;

2. Harga, Pengiriman atau petunjuk lain yang tersedia dalam layanan Shopee;

3. Kelalaian dan kerugian yang ditimbulkan oleh masing-masing Pengguna;

4. Pelanggaran hak atas kekayaan intelektual;

5. Perselisihan antar pengguna;

6. Pencemaran nama baik pihak lain;

7. Setiap penyalahgunaan barang yang sudah dibeli oleh pengguna;

8. Kerugian akibat pembayaran tidak resmi kepada pihak lain selain ke rekening resmi shopee, yang dengan cara apapun mengatasnamakan shopee ataupun kelalaian penulisan rekening dan/atau informasi lainnya dan/atau kelalaian penulisan rekening dan/atau kelalaian pihak bank;

9. Virus atau perangkat lunak berbahaya lainnya yang diperoleh dengan mengakses atau menghubungkan ke layanan shopee; 
10. Kerusakan pada perangkat keras anda dari penggunaan setiap layanan shopee.

\section{Kesimpulan}

Perlindungan hukum kepada konsumen Shopee berdasarkan Undang- Undang Perlindungan Konsumen Nomor 8 Tahun 1999 (UUPK) dan Undang-Undang Informasi dan Transaksi Elektronik Nomor 11 Tahun 2008 (UU ITE) terlihat dari pengaturan mengenai perlindungan hak-hak konsumen dan pemberian ganti rugi. Konsumen yang dirugikan dapat mengajukan tuntutan yang kiranya sejalan dengan UUPK dan UU ITE sehingga memberikan kepastian hukum bagi konsumen. Pemerintah dan masyarakat juga memiliki peran yang penting dalam perlindungan konsumen melalui fungsi pengawasan. Pengawasan tersebut dapat terlihat dari dibentuknya Lembaga Perlindungan Konsumen Swadaya Masyarakat (LPKSM) sebagai wadah untuk secara bersama-sama memperjuangkan, memberikan nasihat, menyebarkan informasi, dan membentu konsumen dalam memperjuangkan hak-haknya. Konsumen yang merasa dirugikan juga dapat melaporkan kerugiannya kepada Yayasan Lembaga Konsumen Indonesia (YLKI) dan Badan Penyelesaian Sengketa Konsumen (BPSK) atau melalui jalur litigasi, Pengawasan terhadap situs e-commerce juga dilakukan, guna menciptakan keamanan dalam bertransaksi.

Bentuk pertanggung jawaban pengelola situs shopee terhadap kerugian yang dialami konsumen telah diatur sepenuhnya melalui syarat dan ketentuan penggunaan layanan yang dapat diakses pada situs belanja shopee. Bentuk pertanggung jawaban tersebut adalah melalui penyediaan sarana pelaporan konsumen mengenai kerugiankerugian yang dialami konsumen, pemblokiran konten-konten negatif, pemberian garansi Shopee, pengembalian dana kepada konsumen, penindaklanjutan akun- akun palsu penjual, serta perlindungan terhadap data-data pribadi dan kartu kredit konsumen, Shopee bertanggung jawab penuh terhadap kerugian konsumen yang terjadi akibat kegagalan pada sistem portal web. Bentuk penggantian kerugian yang diberikan dapat berupa pengembalian dana maupun penggantian barang rusak. Walaupun demikian, Shopee juga memiliki batasan-batasan tanggung jawab. 
Perlindungan Hukum Bagi Konsumen Atas Transaksi Barang Elektronik Melalui Transaksi Jual-Beli Online Shopee

\section{Bibliografi}

Aco, Ambo, \& Endang, Hutami. (2017). Analisis Bisnis E-Commerce pada Mahasiswa Universitas Islam Negeri Alauddin Makassar. Jurnal INSYPRO (Information System and Processing), 2(1).

BPKN, Tim. (2021a). Kajian Perlindungan E-commerce di Indonesia. Retrieved from www.bpkn.go.id

BPKN, Tim. (2021b). Kajian Perlindungan E-Commerce di Indonesia. Retrieved from www.bkpn.go.id website: www.bkpn.go.id

Halim, Abdul Barkatullah. (2010). Hak-Hak Konsumen. Bandung: Nusa Media.

Hardika, Rifan Adi Nugraha Jamaluddin Mukhtar, \& Ardianto, Fajar. (2015). Perlindungan Hukum Terhadap Konsumen Dalam Transaksi Online. Serambi Hukum, 8(02), 23092.

Journal, Tim. (2021). Kapok Belanja di Aplikasi Shopee dan menggunakan kartu kredit citibank. Retrieved from journal.citandy.com website: journal.citandy.com

Konsumen Shopee. (2021). Kebijakan Toko Online Shopee.co.id yang merugikan konsumen. Retrieved from www.kompasiana.com website: www.kompasiana.com

Miru, Ahmadi. (2012). Hukum Kontrak Bernuansa Islam. PT RajaGrafindo Persada.

Nugraha, Peter Mahmud Marzuki dalam Dwi Putra. (2017). Mengamandemen Ketentuan yang Tidak Dapat Diamandemen dalam Konstitusi Republik Indonesia. Cet 1. Yogyakarta: Thafa Media.

Qonsumen, Tim. (2021). Berbelanja di Shopee. Retrieved from www.qonsumen.com website: www.qonsumen.com

Soendari, Tjutju. (2012). Metode Penelitian Deskriptif. Bandung, UPI. Stuss, Magdalena \& Herdan, Agnieszka, 17.

Sunarso, Siswanto. (2009). Hukum informasi dan transaksi elektronik: studi kasus: prita Mulyasari.

Susanto, Happy. (2008). Hak-hak konsumen jika dirugikan. Visimedia.

Tutik, D. R. Titik Triwulan, \& SH, M. H. (2015). Hukum Perdata dalam Sistem Hukum Nasional. Kencana.

Wikipedia, Tim. (2021). Shopee Indonesia. Retrieved from id.wikipedia.com

Zendrato, Josua Dariusman. (2019). Perlindungan hukum bagi konsumen dalam transaksi jual beli online (studi kasus di Toko Zend Ponsel Binjai). Universitas 
Fially Claude Makasuci, Elisatris Gultom

\section{Pelita Harapan.}

http://www.shopee.co.id/syarat-dan-ketentuan-layanan http://www.shopee.co.id/aturan-penggunaan http://www.bkpn.go.id/kajian-perlindungan-ecommerce http://id.wikipedia.com/shopee-indonesia http://www.qonsumen.com/berbelanja-di-shopee http://www.mediakonsumen.com/ylki 